\title{
In Memoriam: Alfred Chandler and the Soul of Business History
}

\author{
CHRISTOPHER D. MCKENNA
}

I never really knew Al Chandler. While my teachers, Lou Galambos, David Hounshell, and Hugh Aitken, were to varying degrees close friends with Chandler, I spoke at length with him only twice. I met Chandler for the first time in 1990 when I was trying to decide where to do my doctorate and I met with him a second time when I held the Chandler Travel Fellowship at the Harvard Business School in 1995 as I was writing my doctoral dissertation. Chandler's scholarship consistently shaped my approach to the study of business history, yet my relationship was always to Chandler's academic research rather than to him as a mentor or as a colleague.

Although I never knew Chandler in a personal sense, I also never knew business history without his overwhelming intellectual presence. Since 1984, when I first studied economic history under Hugh Aitken as an undergraduate at Amherst College, Chandler's work served as the alpha and the omega for my own research and teach-

(C) The Author 2008. Published by Oxford University Press on behalf of the Business History Conference. All rights reserved. For permissions, please e-mail: journals.permissions@oxfordjournals.org.

doi: 10.1093/es/khn053

Advance Access publication June 18, 2008

CHRISTOPHER D. MCKENNA (PhD, The Johns Hopkins University, 2000) is a reader in business history and strategy at the Saïd Business School, a fellow of Brasenose College, and the director of the MBA, all within the University of Oxford. Recent publications include "Writing the Ghost-Writer Back In: Alfred Sloan, Alfred Chandler, John McDonald and the Intellectual Origins of Corporate Strategy," in Management and Organizational History (May 2006), and The World's Newest Profession: Management Consulting in the Twentieth Century (2006) which won both the Hagley Prize of the Business History Conference and the Newcomen-Harvard Book Award of the Business History Review. McKenna is currently at work on his next book, Partners in Crime, an international history of white-collar crime and a set of essays on the intellectual links between business history and organizational theory tentatively titled, Management is History. Contact information: chris.mckenna@sbs.ox.ac.uk. 
ing. Even so Chandler's scholarship continued to surprise me. For example, shortly after I had started my doctoral dissertation on the history of management consulting, I discovered a detailed paragraph in the conclusion of Strategy and Structure describing the overwhelming impact of consultants on the spread of the multidivisional organizational form. As Chandler explained, while American corporate executives had developed the "M-Form" of corporate administration independently during the 1920s, it was the consultants from McKinsey, Booz Allen, and Cresap, McCormick \& Paget who had carried that knowledge from company to company during the 1950s like institutional Johnny Appleseeds. I had always anticipated that my own academic research would intersect with Chandler's scholarship but I had not expected that my earliest archival evidence would follow from his footnotes. Like so many other scholars, my first steps were to follow Chandler's well-blazed trail.

By 1990, when I began my MA in history at the University of Delaware under David Hounshell before moving on to do my PhD at Johns Hopkins under Louis Galambos, Al Chandler had already retired from teaching. Throughout my graduate work in the 1990s, or so it seemed to me, the leading business historians were at work dismantling Chandler's intellectual scaffolding. So it was with some amusement that I learned that academics in strategy within business schools, including Richard Whittington at the University of Oxford where I began teaching in 2000, still revered Chandler as a founding father of their discipline yet few other than Whittington recognized that there were any business historians after Chandler or that his historical scholarship was ever questioned. Of course, institutional sociologists, like Neil Fligstein, and economists, like Oliver Williamson, had long used Chandler's scholarship as a point of departure for their own theoretical work in the social sciences. In business schools, however, Alfred Chandler's name was like a magic incantation that I learned to invoke in order to demonstrate how historians could be relevant to the study of management.

If Chandler's legacy granted me professional legitimacy, however, I also found it hard to put aside my reservations that he did not better contextualize the role of politics or social change in business history. For all the professional power of Chandler's fame-and let me be clear that without Chandler's legacy I doubt that I would now have a tenured job within a leading international business school—Chandler's intellectual paradigm was a yoke that chafed. Like many historians of my generation who were trained as cultural historians, it was not simply the overt whiggishness of Chandler's scholarship that seemed so problematic, but his explicit rejection of alternative explanations from politics or society that made me uneasy. Lou 
Galambos had taught me that Chandler succeeded precisely because he was a hedgehog, and not a fox. Were those who followed Chandler also expected to know just one big thing? The answer, of course, is no. Business history has many facets, and even inside business schools, organizational theorists increasingly study business culture and regulatory politics. To this day, I remain proud not only that my first book, The World's Newest Profession, fleshed out Chandler's description of the diffusion of the multidivision form but that I was able to demonstrate the regulatory, hence the political, origins of management consulting in the New Deal of the 1930s. Just as important to me, I was able to use internal cartoons from McKinsey, not just organization charts from their corporate clients, as historical evidence for the development of the corporate culture of consulting. In my opinion, the most exciting and innovative scholarship in business history has come in recent years from those historians who are as interested in cultural history as Chandlerian business history. For example, consider the work of Bethany Moreton on the links between the ascension of retailing giant Wal-Mart and the growth of Southern Christianity or the research by her colleague Shane Hamilton at the University of Georgia on the development of American trucking networks, both of which won the Krooss Prize for the best doctoral dissertation in business history. Business history need not remain a sterile analysis of administrative structures.

But there still remains one Chandlerian legacy that seems to hang on for no reason. It is a remnant of the Faustian bargain struck in postwar America that subsequent generations of business historians have struggled to overturn. The cold-war mentality of the 1950s drove historians of business to legitimate the "free enterprise" system in the United States whether through funds provided by the Newcomen Society or in the archival resources of Dupont's Hagley Museum. In the early 1960s, as Walt Rostow at MIT set out his "noncommunist manifesto," The Stages of Economic Growth, Al Chandler, also at MIT, published his own stage-theory of business history, Strategy and Structure. In brief, Chandler argued that corporations followed parallel paths in reorganizing their structures of production and distribution as they grew larger and more complex. Although Rostow would suffer widespread criticism for his theory of modernization, Chandler was no less responsible for setting out a unitary model of corporate development. In business history, organizational success and administrative capacity rapidly replaced ethics as the guide to the past. Chandler's successor at Harvard, historian Thomas McCraw, would subsequently praise Chandler for ending the moralizing that led to endless debates over the differences between robber barons and industrial statesmen. Yet to my generation, Chandler's decision to 
abandon ethical judgment in pursuit of pseudo "objective" theories seemed worthy of its own chapter in Peter Novick's classic study, That Noble Dream, chronicling the fruitless search for social-scientific "objectivity" by professional historians. To this day, I continue to find it perplexing that business historians have closer ties to scholars of corporate strategy than to those who study business ethics. Why didn't the business historians choose to ally with the moral philosophers in business schools rather than the game theorists and economists who study strategy?

In retrospect, it is striking how little American business historians had to say (or were asked to say) when Enron, the Houston oil-trading behemoth, collapsed amidst great public uproar in 2001. Although we include historians of accounting, gas pipelines, and financial markets within our scholarly ranks, Chandler's theoretical framework didn't permit business historians to say very much about fraud, corporate corruption, or business ethics. Instead, Richard White, a historian of the American West who teaches at Stanford, provided the necessary framework for analyzing corporate corruption in historical context. By following Chandler's example, American business historians had ceded the long-run perspective on business ethics to outsiders. Only now are business historians, including leading scholars like Louis Galambos (see his analysis of the pharmaceutical giant Merck in The Moral Corporation), finally re-engaging with the implicit moral frameworks that have so long undergirded scholarship produced by the leading historians of labor, politics, and diplomacy. Thus my decision to conclude my first book with an old-fashioned plea for the professionalization of management consulting in large part based on ethical standards-and my choice to pursue a comparative history of white collar crime (pre-Enron) as my next research project-were my modest attempts to inject normative questions of ethics into the overly desiccated, pseudo-objectivity of Chandler's historical synthesis.

As a consequence, I am a business historian who worries that Chandler's intellectual success somehow cost business history its ethical soul. Yet ever the pragmatist, I also recognize that Alfred Chandler was simply responding to the postwar political environment in which he was operating. It is never easy to bite the hand that feeds you. For as a colleague of mine reminded me, when you teach in a business school, you are a running dog of capitalism. Our generation, however, (let's call us the post-Enron historians) is potentially free to renegotiate the cold-war compact that stopped historians from taking up ethical considerations. So as we look back on the legacy of Alfred Chandler let us also look forward to what business historians can still achieve. Human values need not be a hindrance to the scholarly study of the past, even that of business. 